\title{
免震構造物の最適設計解に関寸る不等式 \\ INEQUALITIES ON OPTIMUM DESIGNS OF BASE-ISOLATED STRUCTURES
}

\author{
五十子 幸樹*1，上谷宏二*2 \\ Kohju IKAGO and Koji UETANI
}

\begin{abstract}
In this paper, an optimum design problem of a base-isolated building as a numerical model of the design method which is commonly used in practice is formulated, and is compared with the optimum design method proposed by the authors. Inequalities between the solutions given by two different optimum design methods are shown, and illustrate the charactoristics of these design methods.
\end{abstract}

Keywords: Optimum design, Base isolation, Inequalities, Practical design, Construction cost 最適設計, 免震, 不等式, 実務設計, 建設工事費

\section{1 はじめに}

実務者が免震構造物を設計する場合、先ず初めに免震周期 (免震 層の降伏後剛性から算定される固有周期、以下 $T_{f}$ という記号で表 わす) を決定し、次に免震層降伏剪断力の最適值を求めるという手 順を取る。この場合、免震層の最大応答剪断力を最小とするよう な免震層降伏剪断力が最適值とされている1)2)。

免震層の最大応答剪断力を含む動的応答量は、免震システムの 性能を測る重要な性能量である。免震構造の最適設計に関する既 往の研究において、動的応答量を評価関数としている研究が比較 的多い $($ 例えば3) 6) $)$ のもこの理由によるものと考えられる。ま た、免震層の最大応答尊断力を最小化することで、上・下部構造に 作用する水平力を最小化することは、免震建物全体コストの大部 分を占める上・下部構造のコストを間接的に低減することを意味す る。このため、免震層の最大応答剪断力はコストを測る上でも重 要な性能量となっていると言える。以上のことから、実務において 構造設計者が免震性能とコストの両方に目を配って設計を行ってい ることが良く理解され、この設計手法には一定の合理性があるこ とが指摘できる。

しかしながら、この方法では、設計変数の一つである免震周期 $T_{f}$ を直接的に定める明示的な根拠が示されていない。免震周期の 設定には、過去における免震建物の設計の実績や、構造設計者の 経験が参照されるため、過去に経験のない領域の問題については 試行錯誤が必要である。

これに対して、著者らの提案する最適設計手法 ${ }^{7)}$ では、免震建 物の直接工事費を評価関数とすることで、最適な免震周期とダン パーの最適降伏剪断力を同時に直接的に求めることができると共
に、設計者にとって有用な情報である免震建物の総コストの下界を 得ることができる。

本論文では、以下に示す 2 つの異なる最適設計問題を定式化し、 それらの問題の関連性を調べ、それぞれの解を比較する。

1.【問題 ODBIB】著者らの提案する最適化手法に基づく最適 設計問題で、免震建物全体のコストを評価関数とし、免震層 の降伏後剛性と降伏剪断力を設計変数とした最適設計問題。

2.【問題 ODPR】実務における設計手法の数理モデルとして の最適設計問題で、一次固有周期制約条件下における、免震 層の地震時最大応答眑断力最小化問題。

本論文では問題 ODBIB とその部分問題、及び、問題 ODPR の解の間に成立する不等式を誘導する。著者らは、実用的最適設 計手法を構筑することで設計の論理化を図ることを研究目的の一 つに掲げている。ここで誘導される不等式は、この研究目的の達 成に繫がる成果の一つとして位置づけられる。

\section{2 基本仮定と基礎式}

\section{1 免震建物の一自由度近似と免震層の復元力特性}

一般的な免震建物に対して免震層の応答を考えるとき、上部構 造物は剛体とみなして、免震建物を一自由度系として解析しても実 用上十分な精度で応答を求めることが可能である。また、免震層を 構成する要素は、積層ゴム支承および滑り系支承 (転がり支承又は 弾性滑り支承等を含む) と、履歴ダンパー (鋼材ダンパー、鈶ダン パー等) で構成されるものとし、免震層の復元力特性を Bi-linear 系に単純化して取り扱うものとする。本論文では、免震層の降伏 後剛性を $k_{f}$, ダンパーの降伏塑断力を ${ }_{S} Q_{Y}$ で表す。
*1 侏 日建設計大陏オフィス 構造設計主管・工修

*2 京都大学大学院工学研究科建築学専攻 教授・ 上博
Senior Structural Engineer, Dept. of Structural Engineering, Nikken Sekkei Ltd. M. Eng.

Prof., Dept. of Architecture and Architectural Engineering, Kyoto University, Dr. Eng. 


\section{2 包絡解析法}

免震建物の地震時応答解析手法としては幾つかの方法があり、設 計に当たっては時刻歴応答解析などを含九だ多面的な安全性の検 証を行う必要があることは言うまでも無い。しかしながら、免震建 物の最適設計解の特性を論じることを目的とする場合においては、 エネルギーの釣り合いに着目する方法が動的最大応答を簡便に表 現できるという理由で有利である。従って、本論文では、地震時最 大応答の評価に包絡解析法 ${ }^{2) 8)}$ を用いる。

免震層の地震時最大応答変位を $\delta_{\max }$ 、地震時入力エネルギーの 速度換算値を $V_{E}$ 、上部構造物の総質量を $M\left(\right.$ 定数 $\left.^{1}\right)$ で表すと、地 震時エネルギーの釣り合いは下式のように書ける2)。

$$
\frac{k_{f} \delta_{\max }^{2}}{2}+\kappa \cdot{ }_{S} Q_{Y} \delta_{\max }=\frac{M V_{E}^{2}}{2}
$$

ここに、 $\kappa$ は、免震層の累積塑性変形量と最大変形量の比率であ り、平均的には 8 を用いることができる8)。従って、一般に $\kappa>1$ であるという仮定が十分に成立すると考えられ、以降の議論でも この仮定を用いる。

また、本論文では免震建物という長周期構造物を扱うので、工 ネルギースペクトル $V_{E}$ が建物の固有周期近くの帯域で一定であ るものとして以下の議論を進める。

\section{3 免震建物のコスト関数}

本論文では、免震層について、集約された 3 個の設計変数であ る支承材のバネ定数 (積層ゴム支承の水平バネ定数 $k_{f}$ 及び、すべ り系支承の仮想バネ定数 $\left.k_{s}\right)$ と隇衰要素の降伏塑断力 $\left({ }_{s} Q_{Y}\right)$ の関 数として直接工事費を表す方法を提案する。その式中では、支承 材についてはその部材が支持できる鈶直荷重の単位荷重当たりの 価格、ダンパーについてはその降伏新断力の単位量当たりの単価 が与常数として用いられる。

\subsection{1 支承材の価格}

ここでは、支承材の総コストが設計変数 $k_{f}, k_{s}$ の関数で表現で きることを示し、更にその具体的な関数を提案する。

積層ゴム支承の供給メーカーから提供された価格情報を分析す ると、積層ゴム支承の価格は許容支持荷重に比例すると仮定して も十分な精度でコストを予測できることがわかる。

このことは、同様にすべり系支承でも成り立つ。

積層ゴム支承の許容支持荷重を $W_{R}$ 、すべり系支承の許容支持 荷重を $W_{S}$ と書くこととし、上記の仮定を用いると、以下の関係 が成り立つ。

$$
\begin{aligned}
& \text { 積層ゴム支承の総価格 } C_{I R}=C_{N} W_{R} \\
& \text { すべり系支承の総価格 } C_{I S}=C_{S} W_{S}
\end{aligned}
$$

ここに、 $C_{N}, C_{S}$ はそれぞれ、支承材の単位許容支持荷重あたりの コストであり、任意の通貨単位を有すると考えても良いが、本論文 ではある通貨の単位を有する基準コストで除した無次元のコスト 指標とする。

ある免震層を構成する積層ゴム支承のゴム総厚、単位面積当た りの許容支持面圧、ゴムの剪断弾性剛性、水平断面積の総和をそ れぞれ $t_{R}, \sigma_{0}, G, A_{R}$ で表す。この時、積層ゴム支承によって与え

1 本論文では簡単の為、敦計変数である上部構造物の部材寸法が変化しても上 部構造物の総質量は変化しないという仮定を設ける。実際、最適解の近傍では、 設郭変数の変化に伴う上部構造物の質量の変化は小さく、無視し得る程度である。 また、構造設計の実務においても構造部材の変更が地震荷重算定用の建物重量に 影響を与えないことは広く了解されている。
られる水平バネ定数の総和 $k_{f}$ は次式で表せる。

$$
k_{f}=\frac{G A_{R}}{t_{R}}
$$

免震支承の設計においては、鈶直荷重を安全に支持しながら、目 標とする免震周期を実現するための水平バネの調整が必要となる。

滑り系支承が水平剛性を有しないのに対して、積層ゴム支承の 水平剛性は、使用するゴムの剪断弾性剛性、ゴム層厚、基準面圧、 ゴムの水平断面積を変化させることで調整できる。しかしながら、 本研究では、ゴムの剪断弾性剛性、ゴム層厚、基準面圧を定数とし て扱う。

免震層に配置される個々の積層ゴム支承の剪断弾性剛性、ゴム 層厚、基準面圧を変化させる問題を扱うには、個々の積層ゴムにつ いてそれぞれ設計変数を有するような問題を定式化する必要があ るが、本論文では、免震層の設計において、免震層全体の水平剛性 を設計変数とする単純問題を定式化して、免震建物の最適設計解 の閉形表現を導き、解の性質を論じることを目的としているため、 個々の支承材の設計を行うような問題は取り扱わない。

また、実務の設計においても、1 つの免震建物の中で様々な剪断 弾性剛性や基準面圧を有する積層ゴム支承が混在する設計は避け られるのが一般的である。

この理由として、

1. 免震層に配置されたすべての積層ゴムには、同じ水平変形が 生じるが、ゴム総厚を一定とすれば、ゴムの剪断歪もすべて の積層ゴムに対して同じとなり、剪断丕に依存する特性がす べての積層ゴム支承で均一となる。

2. ゴムの剪断弾性剛性、ゴム層厚がそろっていて、各支承の面 圧が基淮面圧近傍になるように水平断面積が調整されておれ ば、上部構造物の重心と、積層ゴム支承群の剛心が一致する。 などがあげられる。

このように、ここで導入した仮定は実務で行われている設計手 法を説明するにあたり大きな障害とはならない。

本論文では、免震層の水平バネ定数を積層ゴム支承とすべり系 支承の組み合わせ方で調整する手法を提案する。これは、上部構 造物の重量を積層ゴム支承と滑り系支承に如何に振り分けるかを 決定する問題と等価である。

積層ゴム支承の水平断面積の総和 $A_{R}$ で支持できる鉣直荷重 $W_{R}$ は次式で表せる。

$$
W_{R}=\sigma_{0} A_{R}
$$

(4),(5) 式より、免震層の降伏後剛性 $k_{f}$ と積層ゴム支承の許容支 持鈆直荷重 $W_{R}$ の間に成り立つ関係式、

$$
k_{f}=\frac{G}{t_{R} \sigma_{0}} W_{R}
$$

が導ける。

同様に、滑り支承の許容鈶直支持荷重を $W_{S}$ 、上部構造物の総 重量を $\mathrm{W}$ とそれぞれおき、 $(6)$ 式の $W_{R}$ の項を $W$ 及び $W_{S}$ で置 き換えて次の 2 式を得る。

$$
\begin{aligned}
& k_{0}=\frac{G}{t_{R} \sigma_{0}} W \\
& k_{s}=\frac{G}{t_{R} \sigma_{0}} W_{S}
\end{aligned}
$$

ここに、 $k_{0}$ は上部構造物の重量と積層ゴム支承の許容鈶直支持荷 重が一致するときの $k_{f}$ を表している。 
これに対して、 $k_{s}$ は実質的なばね定数ではない。重量 $W_{S}$ を積 層ゴム支承で支持すると $k_{s}$ という水平バネ定数が与えら机るとこ ろであるが、これを滑り支承としたために、重量 $W_{S}$ に対応する バネ定数が 0 となっている。即ち、この $k_{s}$ というバネ定数は仮想 バネ定数であり、積層ゴム支承を用いる代わりに滑り支承を用いる ことにより隇じられる免震層の降伏後剛性と解釈できる。

次に、これらバネ定数とコストの関係を導く。

(6),(8) 式より次式を得る。

$$
\begin{aligned}
& W_{R}=\frac{t_{R} \sigma_{0}}{G} k_{f} \\
& W_{S}=\frac{t_{R} \sigma_{0}}{G} k_{s}
\end{aligned}
$$

これを、(2),(3) 式に代入して、次式を得る。

$$
\begin{aligned}
& C_{I R}=\frac{C_{N} t_{R} \sigma_{0}}{G} k_{f} \\
& C_{I S}=\frac{C_{S} t_{R} \sigma_{0}}{G} k_{s}
\end{aligned}
$$

上式において、 $k_{f}, k_{s}$ の係数は定数となるので、それぞれを $\alpha_{1}, \alpha_{2}$ とおくと、

$$
\left\{\begin{array}{l}
\alpha_{1}=\frac{C_{N} t_{R} \sigma_{0}}{G} \\
\alpha_{2}=\frac{C_{S} t_{R} \sigma_{0}}{G}
\end{array}\right.
$$

となり、

(11),(12) 式は以下のようになる。

$$
\begin{aligned}
& C_{I R}=\alpha_{1} k_{f} \\
& C_{I S}=\alpha_{2} k_{s}
\end{aligned}
$$

\section{3 .2 ダンパーの価格}

鈶ダンパーや鋼材系の履歴ダンパーの降伏剪断力は、ダンパー として用いられる材料の数量に比例する。更に、ダンパーを構成 する材料の数量と、そのコストは比例関係にあるから、ダンパー のコスト $C_{D}$ は、降伏盆断力に比例する。その比例係数を $\beta$ とお くと、ダンパーのコスト $C_{D}$ は次式で表される。

$$
C_{D}=\beta \cdot{ }_{S} Q_{Y}
$$

\subsection{3 免震層のコスト関数}

以上より、免震層全体のコスト関数は以下のように定義できる。

$C_{I}\left(\boldsymbol{X}_{I}\right)=C_{I R}+C_{I S}+C_{D}=\alpha_{1} k_{f}+\alpha_{2} k_{s}+\beta \cdot{ }_{S} Q_{Y}$

\section{4 免震層の地震時最大応答剪断力}

免震層の地震時最大応答剪断力は、免震層の支承材が負担する 剪断力とダンパーが負担する剪断力の総和であるから、下式で表 される。

$$
Q_{B}=k_{f} \delta_{\max }+{ }_{S} Q_{Y}
$$

地震時最大応答剪断力 $Q_{B}$ は、(1) 式を $\delta_{\max }$ について解き、(18) 式に代入することで免震層の設計変数 $X_{I}$ の関数として表現でき る。これを、 $\widehat{Q}_{B}\left(\boldsymbol{X}_{I}\right)$ とおくと、

$$
Q_{B}=\widehat{Q}_{B}\left(\boldsymbol{X}_{I}\right)=(1-\kappa) \cdot{ }_{S} Q_{Y}+\sqrt{\kappa^{2} \cdot{ }_{S} Q_{Y}^{2}+k_{f} M V_{E}^{2}}
$$

$$
\text { と畫ける。 }
$$

\section{3 最適設計問題}

以下に、著者らが提案する最適設計問題と寒務における設計手 法の数理モデルとしての最適設計問題を定式化する。

\section{1 コスト最小設計問題}

ここでは、既報7)で定式化した最適設計問題を再度整理して提 示する。

免震建物全体のコストを評価関数とし、免震層の降伏後剛性と 降伏剪断力を設計変数とした最適設計問題の原問題 (Optimum Design problem of a Base-Isolated Building) は以下のように 書ける。

\section{最適設計問題 ODBIB(原問題)}

Find $\boldsymbol{X}$

to Minimize $O_{B J}(\boldsymbol{X})$

Subject to $\boldsymbol{g}(\boldsymbol{X}, \boldsymbol{R}(\boldsymbol{X})) \leq \mathbf{0}$

ここに、X は、免震層の設計変数 $\boldsymbol{X}_{I}=\left\{k_{f}, k_{s},{ }_{S} Q_{Y}\right\}^{T}$ 之 上・下部構造の各部材の寸法等の設計変数 $\boldsymbol{X}_{U L}$ からなる免震建物 の設計変数べクトルを表わす。即ち、 $\boldsymbol{X}=\left\{\boldsymbol{X}_{U L}, \boldsymbol{X}_{I}\right\}$ である。 $\boldsymbol{X}_{U L}$ の具体的成分は、上・下部構造部材の寸法、鉄筋径・鉄筋本 数 ( $\mathrm{RC}$ 造の場合)、鋼材の板厚 ( $\mathrm{S}$ 又は $\mathrm{SRC}$ 造の場合) 等である。 また、 $O_{B J}(\boldsymbol{X})$ は上・下部構造及び免震層のコストの総和を、 $\boldsymbol{R}(\boldsymbol{X})$ は免震建物の設計用外力に対する応答量を成分として有す るべクトルを、 $\boldsymbol{g}(\boldsymbol{X}, \boldsymbol{R}(\boldsymbol{X})) \leq \mathbf{0}$ は、設計対象の建物が満たすべ き個々の制約条件をべクトルで表現したものである。

免震建物が一自由度系で近似できるという仮定の下では、この 問題は以下に示すような、免震層の最適設計問題 ODBIS と、上・ 下部構造物の最適設計問題 ODUL の 2 つに分割できる。これら の 2 つの問題においては、それぞれ個別に最適化が行われるが、建 物全体としての最適解を求めるために免震層と上・下部構造の設 計問題を接続するパラメータである免震層の地震時最大応答剪断 力 $Q_{B}^{*}$ (定数) を設計変数 $X_{Q B}$ に置き換えた問題 ODWB が定式 化される。

このように、最適設計問題を部分問題に分割し、その後に各部 分問題を接続するパラメー夕を設計変数として全体問題を再定式 化する手法を著者らは二段階設計法と呼んでいる。

以下、各部分問題とその最適解を提示する。

最適設計問題 ODBIS(免震層の最適設計問題)

Find $\boldsymbol{X}_{I}$

to Minimize $C_{I}\left(\boldsymbol{X}_{I}\right)$

Subject to $\left\{\begin{array}{l}\widehat{Q}_{B}\left(\boldsymbol{X}_{I}\right) \leq Q_{B}^{*} \\ \boldsymbol{g}_{I}\left(\boldsymbol{X}_{I}, \boldsymbol{R}_{I}\left(\boldsymbol{X}_{I}\right)\right) \leq \mathbf{0}\end{array}\right.$

ここに、 $g_{I}$ はべクトル $g$ の内、免震層の設計変数や応答量に関係 する制約条件のみを成分として有するべクトルである。

上部構造物は、2 種類の支承材により安全に支持されなければ ならないから、次式が成り立つ。

$$
W \leq W_{R}+W_{S}
$$

上式の両辺に、 $\frac{G}{t_{R} \sigma_{0}}$ を乗じて変形すると、 $(6) \sim(8)$ 式より、次式 のような制約条件式を得る。

$$
k_{0}-k_{f}-k_{s} \leq 0
$$

この式の左辺は、ベクトル $\boldsymbol{g}_{I}$ の具体的な成分の一つである。

これに、設計変数 $k_{f}, k_{s},{ }_{S} Q_{Y}$ の非負条件を加えて $\boldsymbol{g}_{I}$ の具体 的表現が次式である場合について、最適性の必要条件とそれを満 
たす解の閉形表現を導出する。

$$
\boldsymbol{g}_{I}=\left\{-k_{f},-k_{s}, k_{0}-k_{f}-k_{s},-{ }_{S} Q_{Y}\right\}^{T}
$$

この最適設計問題の解が満たすべき条件は Lagrangian function $L$ を以下のように定義した時、

$$
\begin{aligned}
L= & \alpha_{1} k_{f}+\alpha_{2} k_{s}+\beta \cdot{ }_{S} Q_{Y}-\lambda_{1} k_{f}-\lambda_{2} k_{s} \\
& -\lambda_{3} \cdot{ }_{S} Q_{Y}+\lambda_{4}\left(k_{0}-k_{f}-k_{s}\right)+\lambda_{5}\left(\widehat{Q}_{B}-Q_{B}^{*}\right)
\end{aligned}
$$

以下に示す $\mathrm{KKT}$ 条件と呼ばれる条件 $\left.{ }^{9)} 10\right)$ で記述することができる。

$$
\begin{aligned}
& \frac{\partial L}{\partial k_{f}}=\alpha_{1}-\lambda_{1}-\lambda_{4} \\
& \quad+\lambda_{5} \frac{M V_{E}^{2}}{2 \sqrt{\kappa^{2} \cdot{ }_{S} Q_{Y}^{2}+M V_{E}^{2} k_{f}}}=0 \\
& \frac{\partial L}{\partial k_{s}}= \alpha_{2}-\lambda_{2}-\lambda_{4}=0 \\
& \frac{\partial L}{\partial_{S} Q_{Y}}= \beta-\lambda_{3}+\lambda_{5}\left(1-\kappa+\frac{\kappa^{2} \cdot{ }_{S} Q_{Y}}{\sqrt{\kappa^{2} \cdot{ }_{S} Q_{Y}^{2}+M V_{E}^{2} k_{f}}}\right) \\
&= 0 \\
& \frac{\partial L}{\partial \lambda_{1}}=-k_{f} \leq 0 \\
& \frac{\partial L}{\partial \lambda_{2}}=-k_{s} \leq 0 \\
& \frac{\partial L}{\partial \lambda_{3}}=-S_{Y} Q_{Y} \leq 0 \\
& \frac{\partial L}{\partial \lambda_{4}}= k_{0}-k_{f}-k_{s} \leq 0 \\
& \frac{\partial L}{\partial \lambda_{5}}= \widehat{Q}_{B}-Q_{B}^{*} \leq 0 \\
& \quad \lambda_{i} \geq 0 \quad(i=1,2,3,4,5) \\
& \quad-\lambda_{1} k_{f}-\lambda_{2} k_{s}-\lambda_{3} \cdot{ }_{S} Q_{Y} \\
& \quad+\lambda_{4}\left(k_{0}-k_{f}-k_{s}\right)+\lambda_{5}\left(Q_{B}-Q_{B}^{*}\right)=0
\end{aligned}
$$

ここに、 $\lambda_{i}(i=1,2,3,4,5)$ は、Lagrange 乗数である。

一般に次式が成立するため ${ }^{7)}$ 、

$$
\frac{M V_{E}^{2} \beta^{2}}{\alpha_{3}^{2} k_{0}}<4(\kappa-1)^{2}
$$

$Q_{B}^{*}$ に関して解の存在する 4 つの領域、

$$
\begin{aligned}
& \boldsymbol{B}_{0}=\left\{Q_{B}^{*} ; Q_{B}^{*}>\sqrt{M V_{E}^{2} k_{0}}\right\} \\
& \boldsymbol{B}_{I}=
\end{aligned}
$$

$\left\{Q_{B}^{*} ; \frac{1}{\kappa} \sqrt{\left(\frac{M V_{E}^{2} \beta}{2 \alpha_{3}}\right)^{2}+(2 \kappa-1) M V_{E}^{2} k_{0}} \leq Q_{B}^{*}<\sqrt{M V_{E}^{2} k_{0}}\right\}$

$\boldsymbol{B}_{I I}=$

$\left\{Q_{B}^{*} ; \frac{M V_{E}^{2} \beta}{2(\kappa-1) \alpha_{3}} \leq Q_{B}^{*}<\frac{1}{\kappa} \sqrt{\left(\frac{M V_{E}^{2} \beta}{2 \alpha_{3}}\right)^{2}+(2 \kappa-1) M V_{E}^{2} k_{0}}\right\}$

$\boldsymbol{B}_{I I I}=\left\{Q_{B}^{*} ; 0<Q_{B}^{*}<\frac{M V_{E}^{2} \beta}{2(\kappa-1) \alpha_{3}}\right\}$

$$
\text { ここに、 } \alpha_{3}=\alpha_{2}-\alpha_{1}
$$

が定義でき、それぞれの領域に対して閉形解が得られる。

既報7)で示したように実務上実質的な最適設計解として受け入 れられるのは $Q_{B}^{*} \in\left(\boldsymbol{B}_{I} \cup \boldsymbol{B}_{I I}\right)$ の場合であるから、今後の議論 のため次の領域を定義しておく。

$$
\boldsymbol{B}=\boldsymbol{B}_{I} \cup \boldsymbol{B}_{I I}
$$

$\boldsymbol{g}_{I}$ の成分として (22) 式の他に制約条件がある場合は、次の $2 つ$ 領域を定義しておく必要がある。

$$
\begin{aligned}
& \boldsymbol{B}_{I}^{C}=\left\{Q_{B}^{*} ; Q_{B}^{*} \in \boldsymbol{B}_{I} \text { かつ、 } \boldsymbol{g}_{I} \leq \mathbf{0}\right\} \\
& \boldsymbol{B}_{I I}^{C}=\left\{Q_{B}^{*} ; Q_{B}^{*} \in \boldsymbol{B}_{I I} \text { かつ、 } \boldsymbol{g}_{I} \leq \mathbf{0}\right\}
\end{aligned}
$$

更に、

$$
\boldsymbol{B}^{C}=\boldsymbol{B}_{I}^{C} \cup \boldsymbol{B}_{I I}^{C}
$$

とおく。

この問題の解は、 $Q_{B}^{*}$ をパラメータとして得られるので、下式 のような形で畵くことができる。

$$
\begin{aligned}
k_{f} & =\widetilde{k}_{f}\left(Q_{B}^{*}\right) \\
{ }_{S} Q_{Y} & ={ }_{S} \widetilde{Q}_{Y}\left(Q_{B}^{*}\right) \\
C_{I} & =\widetilde{C}_{I}\left(Q_{B}^{*}\right)
\end{aligned}
$$

これらの閉形表現については既報7)で $\kappa=8$ の場合について示し た。その一般的表現は以下のようになる。

0) $Q_{B}^{*} \in \boldsymbol{B}_{0}$ の時、

この時、免震層の最適設計解は滑り支承なしで決定され、最適 設計解は、

$$
\begin{aligned}
\widetilde{k}_{f}\left(Q_{B}^{*}\right) & =k_{0} \\
\widetilde{k}_{s}\left(Q_{B}^{*}\right) & =0 \\
{ }_{S} \widetilde{Q}_{Y}\left(Q_{B}^{*}\right) & =0 \\
\widetilde{C}_{I}\left(Q_{B}^{*}\right) & =\alpha_{1} k_{0}
\end{aligned}
$$

で表される。

この場合の解は、本論文の後半の議論において一貫性を保持す るために提示したものであり、数学的には最適性の条件 (KKT 条 件) を満たすが、ダンパーの降伏剪断力が 0 となるため実務的には 受け入れ難い解である。

1) $Q_{B}^{*} \in \boldsymbol{B}_{I}$ の時、

この時、免震層の最適設計解は滑り支承なしで決定され、最適 設計解は、

$$
\begin{aligned}
& \widetilde{k}_{f}\left(Q_{B}^{*}\right)=k_{0} \\
& \widetilde{k}_{s}\left(Q_{B}^{*}\right)=0
\end{aligned}
$$

${ }_{S} \widetilde{Q}_{Y}\left(Q_{B}^{*}\right)=\frac{(\kappa-1) Q_{B}^{*}-\sqrt{\kappa^{2} Q_{B}^{* 2}-(2 \kappa-1) M V_{E}^{2} k_{0}}}{2 \kappa-1}(52)$

$\widetilde{C}_{I}\left(Q_{B}^{*}\right)=$

$$
\alpha_{1} k_{0}+\beta \frac{(\kappa-1) Q_{B}^{*}-\sqrt{\kappa^{2} Q_{B}^{* 2}-(2 \kappa-1) M V_{E}^{2} k_{0}}}{2 \kappa-1}
$$

で表される。

2) $Q_{B}^{*} \in \boldsymbol{B}_{I I}$ の時、

この時、免震層の最適設計解は滑り支承ありの条件で決定され、 最適設計解は、

$$
\begin{aligned}
\widetilde{k}_{f}\left(Q_{B}^{*}\right) & =\frac{1}{(2 \kappa-1) M V_{E}^{2}}\left\{\kappa^{2} Q_{B}^{* 2}-\left(\frac{M V_{E}^{2} \beta}{2 \alpha_{3}}\right)^{2}\right\} \\
\widetilde{k}_{s}\left(Q_{B}^{*}\right) & =k_{0}-\frac{1}{(2 \kappa-1) M V_{E}^{2}}\left\{\kappa^{2} Q_{B}^{* 2}-\left(\frac{M V_{E}^{2} \beta}{2 \alpha_{3}}\right)^{2}\right\} \\
{ }_{S} \widetilde{Q}_{Y}\left(Q_{B}^{*}\right) & =\frac{1}{2 \kappa-1}\left((\kappa-1) Q_{B}^{*}-\frac{M V_{E}^{2} \beta}{2 \alpha_{3}}\right)
\end{aligned}
$$




$$
\begin{aligned}
\widetilde{C}_{I}\left(Q_{B}^{*}\right)=- & \frac{\kappa^{2} \alpha_{3} Q_{B}^{* 2}}{(2 \kappa-1) M V_{E}^{2}}+\alpha_{2} k_{0} \\
& +\frac{(\kappa-1) \beta Q_{B}^{*}}{2 \kappa-1}-\frac{M V_{E}^{2} \beta^{2}}{(2 \kappa-1) \alpha_{3}}
\end{aligned}
$$

で表される。

3) $Q_{B}^{*} \in \boldsymbol{B}_{I I I}$ の時、

この時、免震層の最適設計解は滑り支承ありの条件で決定され、 最適設計解は、

$$
\begin{aligned}
\widetilde{k}_{f}\left(Q_{B}^{*}\right) & =\frac{Q_{B}^{* 2}}{M V_{E}^{2}} \\
\widetilde{k}_{s}\left(Q_{B}^{*}\right) & =k_{0}-\frac{Q_{B}^{* 2}}{M V_{E}^{2}} \\
{ }_{S} \widetilde{Q}_{Y}\left(Q_{B}^{*}\right) & =0 \\
\widetilde{C}_{I}\left(Q_{B}^{*}\right) & =\alpha_{1} k_{0}-\alpha_{3} \frac{Q_{B}^{* 2}}{M V_{E}^{2}}
\end{aligned}
$$

で表される。

この場合の解も 0) の場合と同様、本論文の後半の議論において 一貫性を保持するために提示したものであり、数学的には最適性の 条件を满たすが、ダンパーの降伏剪断力が 0 となるため実務的に は受け入れ難以解である。

次に上・下部構造の最適設計問題は以下のように書ける。

\section{最適設計問題 ODUL(上・下部構造の最適設計問題)} Find $\boldsymbol{X}_{U L}$

to Minimize $C_{U L}\left(\boldsymbol{X}_{U L}\right)$

Subject to $\boldsymbol{g}_{U L}\left(\boldsymbol{X}_{U L}, \boldsymbol{R}_{U L}\left(\boldsymbol{X}_{U L} ; Q_{B}^{*}\right)\right) \leq \mathbf{0}$

ここに、 $\boldsymbol{g}_{U L}\left(\boldsymbol{X}_{U L}, \boldsymbol{R}_{U L}\left(\boldsymbol{X}_{U L} ; Q_{B}^{*}\right)\right)$ は、免震層の地震時最大応 答剪断力の上限值 $Q_{B}^{*}$ に基づいて決定される上・下部構造物の設 計用外力に対する上・下部構造の応答に関する制約条件を表わして いる。 $C_{U L}\left(\boldsymbol{X}_{U L}\right)$ は、上・下部構造物のコス卜関数である。この 問題の最適解は $Q_{B}^{*}$ をパラメータとした表現となり、一般的に以 下のように書ける。

$$
\begin{aligned}
\boldsymbol{X}_{U L} & =\widetilde{\boldsymbol{X}}_{U L}\left(Q_{B}^{*}\right) \\
C_{U L} & =\widetilde{C}_{U L}\left(Q_{B}^{*}\right)
\end{aligned}
$$

原問題 ODBIB は、上記の 2 つの部分問題を組み合わせること で定数 $Q_{B}^{*}$ に対応する設計変数 $X_{Q B}$ を用いた次のような問題に 再定式化できる。

\section{最適設計問題 ODWB}

Find $X_{Q B} \in \boldsymbol{B}^{C}$

to Minimize $C^{O D}\left(X_{Q B}\right)$

ここで、 $C^{O D}\left(X_{Q B}\right)$ は、建物全体のコストを $X_{Q B}$ の関数として 書き直したもので。下式で定義される。

$$
C^{O D}\left(X_{Q B}\right)=\widetilde{C}_{U L}\left(X_{Q B}\right)+\widetilde{C}_{I}\left(X_{Q B}\right)
$$

この問題の最適設計解が $X_{Q B}=Q_{B}^{o p t}$ で表わされているとき、上 下部構造の設計解 $\boldsymbol{X}_{U L}$ 、免震層の設計解 $\boldsymbol{X}_{I}$ は以下のように書 ける。

$$
\begin{aligned}
\boldsymbol{X}_{U L} & =\widetilde{\boldsymbol{X}}_{U L}\left(Q_{B}^{o p t}\right) \\
\boldsymbol{X}_{I} & =\widetilde{\boldsymbol{X}}_{I}\left(Q_{B}^{o p t}\right) \\
k_{f} & =\widetilde{k}_{f}\left(Q_{B}^{o p t}\right) \\
k_{s} & =\widetilde{k}_{s}\left(Q_{B}^{o p t}\right) \\
s Q_{Y} & ={ }_{S} \widetilde{Q}_{Y}\left(Q_{B}^{o p t}\right)
\end{aligned}
$$

3.2 一次固有周期指定条件下の免震層最大応答剪断力最小化問題 免震周期 $T_{f}$ と免震層の降伏後剛性 $k_{f}$ の間には下式が成立する。

$$
T_{f}=2 \pi \sqrt{\frac{M}{k_{f}}}
$$

下記に示す理由により、実務における設計手法の数理モデルは、 後に述べる最適設計問題 ODPR のように一次固有周期が予定数と して与えられている問題として定式化することが適切である。

1. 免震層の最大応答剪断力を評価関数とした設計手法において は、免震周期を設計変数としてしまうと、無限大の周期が最適 であるという結果になってしまい、合理的な解が得られない。

2. 実務設計においては、構造設計者が過去の経験・実績を参照 し、かつ判断のよりぞころとしながら、同時に設計対象とす る建物に要求される性能やコストなどの様々な制約条件を総 合的に勘案して免震周期を決定しているのが実情である。

次に示す最適設計問題 ODPR(Optimum Design problem as a numerical model of the PRactical design method) では、免 震周期 $T_{f}$ が $T_{f}^{*}$ という定数で与えられている。この時の免震層の 降伏後剛性を $k_{f}^{*}$ (定数) とおくと、これは下式のようになる。

$$
k_{f}^{*}=\frac{4 \pi^{2} M}{T_{f}^{* 2}}
$$

\section{最適設計問題 ODPR}

(一次固有周期指定条件下の免震㒶最大応答剪断力最小化問題)

Find ${ }_{S} Q_{Y}$

to Minimize $\widehat{Q}_{B}\left(k_{f}^{*},{ }_{S} Q_{Y}\right)$

$\kappa=8$ とした時、この問題の解 $s \check{Q}_{Y}\left(T_{f}^{*}\right)$ は以下のようになるこ とが既に知られている1)2)。

$$
{ }_{S} \check{Q}_{Y}\left(T_{f}^{*}\right)=\frac{7 \pi M V_{E}}{4 \sqrt{15} T_{f}^{*}}
$$

この解は、より一般的には、以下のように書ける。

$$
{ }_{S} \breve{Q}_{Y}\left(T_{f}^{*}\right)=\frac{2(\kappa-1) \pi M V_{E}}{\kappa \sqrt{2 \kappa-1} T_{f}^{*}}
$$

ここに、 $T_{f}^{*}$ の関数 ${ }_{S} \breve{Q}_{Y}\left(T_{f}^{*}\right)$ は、 $T_{f}^{*}$ の与える免震ダンパーの最 適降伏剪断力を表わす。

故にこの時の評価関数 $\widehat{Q}_{B}$ の値を $Q_{B}^{\text {Topt }}\left(T_{f}^{*}\right)$ と書くと、

$$
Q_{B}^{T o p t}\left(T_{f}^{*}\right)=\widehat{Q}_{B}\left(k_{f}^{*}, \frac{2(\kappa-1) \pi M V_{E}}{\kappa \sqrt{2 \kappa-1} T_{f}^{*}}\right)=\frac{2 \sqrt{2 \kappa-1} \pi M V_{E}}{\kappa T_{f}^{*}}
$$

となる。

問題 ODPR の最適解の与える免震痐のコストを $\check{C}_{I}\left(T_{f}^{*}\right)$ で表 わすこととすると、(17),(71),(73) 式より下式を得る。

$$
\check{C}_{I}\left(T_{f}^{*}\right)=-\frac{4 \alpha_{3} \pi^{2} M}{T_{f}^{* 2}}+\alpha_{2} k_{0}+\frac{2(\kappa-1) \beta \pi M V_{E}}{\kappa \sqrt{2 \kappa-1} T_{f}^{*}}
$$

また、問題 ODPR の最適解が与える上部構造物の設計解は (62),(63) 式より次のようになる。

$$
\begin{aligned}
\boldsymbol{X}_{U L} & =\widetilde{\boldsymbol{X}}_{U L}\left(Q_{B}^{T o p t}\left(T_{f}^{*}\right)\right) \\
C^{P R}\left(T_{f}^{*}\right) & =\widetilde{C}_{U L}\left(Q_{B}^{T o p t}\left(T_{f}^{*}\right)\right)+\check{C}_{I}\left(T_{f}^{*}\right)
\end{aligned}
$$

ここに、 $C^{P R}\left(T_{f}^{*}\right)$ は問題 ODPR の最適解が与える免震建物全体 のコストである。 


\section{4 最適設計解の上界}

3.1 節の (50),(54) 式で示したように、著者らが提案する最適設 計手法で得られる最適解のうち、免震層の降伏後剛性 $k_{f}$ の存在範 囲は $0<k_{f} \leq k_{0}$ である。

実務設計においても、上部構造物の重量を安全に支持するため に最低限必要な支承材の水平断面積を超えて支承材を配置するこ とは一般的には行われないことから、最適設計問題 ODPR の設計 変数 $k_{f}$ について $0<k_{f} \leq k_{0}$ なる変域を設けても広く一般に受 け入れられるであろう。

以上より、著者らの提案する最適設計問題 ODBIB 及びその部 分問題 ODBIS、並びに実務設計手法の数理モデルとしての問題 ODPR に共通する $k_{f}$ に関する解の上界は $k_{0}$ である。

$k_{f}$ に変域が存在することは、免震周期 $T_{f}$ にも変域が存在する ことを意味し、 $T_{f}$ の変域 $\boldsymbol{B}_{T f}$ は以下のように定義できる。

$$
\boldsymbol{B}_{T f}=\left\{T_{f} ; T_{f}>2 \pi \sqrt{\frac{M}{k_{0}}}\right\}
$$

免震層の最適降伏剪断力についても、問題 ODBIS,ODPR それぞ れについて上界が与えられることを以下に示す。

系 1. 問題 ODBIS における免票層の最適降伏前断力の上界 問題 ODBIS において免震層の最適降伏剪断力 ${ }_{S} \widetilde{Q}_{Y}\left(X_{Q B}\right)$ に は上界が存在し、 $\forall X_{Q B}>0$ に対して以下の不等式が成り立つ。

$$
{ }_{S} \widetilde{Q}_{Y}\left(X_{Q B}\right) \leq{ }_{S} \bar{Q}_{Y}
$$

ここに、

${ }_{S} \bar{Q}_{Y}=\frac{\kappa-1}{\kappa(2 \kappa-1)} \sqrt{\left(\frac{M V_{E}^{2} \beta}{2 \alpha_{3}}\right)^{2}+(2 \kappa-1) M V_{E}^{2} k_{0}}-\frac{M V_{E}^{2} \beta}{2(2 \kappa-1) \alpha_{3}}$

${ }_{S} \bar{Q}_{Y}$ は最適解が図 1 の(2)点にある場合の ${ }_{S} \widetilde{Q}_{Y}\left(X_{Q B}\right)$ を示して いる。

図 1 に破線で示すように、ODBIS の解は変数 $X_{Q B}$ の增大と 共に、領域 II においては(2)点を通る放物線上を、領域 I において は直線 $k_{f}=k_{0}$ 上を移動する。最適降伏剪断力 ${ }_{S} \widetilde{Q}_{Y}\left(X_{Q B}\right)$ は、 (2)点において最大值をとることが分かる。

以下、このことを数学的に証明する。

【系 1.の証明】

1) $X_{Q B} \in \boldsymbol{B}_{I}$ の時の最適解 (52) 式において定数 $Q_{B}^{*}$ を設計変 数 $X_{Q B}$ で置き換え、更にその右辺を $X_{Q B}$ に関して微分すると下 式を得る。

$$
\begin{aligned}
\frac{d_{S} Q_{Y}\left(X_{Q B}\right)}{d X_{Q B}} & =\frac{\kappa-1}{2 \kappa-1}-\frac{\kappa^{2} X_{Q B}}{(2 \kappa-1) \sqrt{\kappa^{2} X_{Q B}^{2}-(2 \kappa-1) M V_{E}^{2} k_{0}}} \\
& <\frac{\kappa-1}{2 \kappa-1}-\frac{\kappa^{2} X_{Q B}}{(2 \kappa-1) \sqrt{\kappa^{2} X_{Q B}^{2}}} \\
& =-\frac{1}{2 \kappa-1}<0
\end{aligned}
$$

故に、 $X_{Q B} \in \boldsymbol{B}_{I}$ の時、 ${ }_{S} \widetilde{Q}_{Y}\left(X_{Q B}\right)$ は単調減少関数だか ら、 $X_{Q B}=\frac{1}{\kappa} \sqrt{\left(\frac{M V_{E}^{2} \beta}{2 \alpha_{3}}\right)^{2}+(2 \kappa-1) M V_{E}^{2} k_{0}}$ の時最大值、 $\frac{\kappa-1}{\kappa(2 \kappa-1)} \sqrt{\left(\frac{M V_{E}^{2} \beta}{2 \alpha_{3}}\right)^{2}+(2 \kappa-1) M V_{E}^{2} k_{0}}-\frac{M V_{E}^{2} \beta}{2(2 \kappa-1) \alpha_{3}}$ $={ }_{S} \bar{Q}_{Y}$ をとる。
よって、 $\forall X_{Q B} \in \boldsymbol{B}_{I}$ に対して、 ${ }_{S} \widetilde{Q}_{Y}\left(X_{Q B}\right) \leq{ }_{S} \bar{Q}_{Y}$

2) $X_{Q B} \in \boldsymbol{B}_{I I}$ の時の最適解 $(56)$ 式は $X_{Q B}$ に関す る一次関数で表されているので、この領域の $X_{Q B}$ の最大 值 $\frac{1}{\kappa} \sqrt{\left(\frac{M V_{E}^{2} \beta}{2 \alpha_{3}}\right)^{2}+(2 \kappa-1) M V_{E}^{2} k_{0}}$ を代入することで、 $\max _{X_{Q B} \in \boldsymbol{B}_{I I}}{ } \widetilde{Q}_{Y}\left(X_{Q B}\right)={ }_{S} \bar{Q}_{Y}$ が確かめられる。

3) $X_{Q B} \in\left(\boldsymbol{B}_{0} \cup \boldsymbol{B}_{I I I}\right)$ の時、 ${ }_{S} \widetilde{Q}_{Y}\left(X_{Q B}\right)=0<{ }_{S} \bar{Q}_{Y}$

上記 1) 3) より、 $\forall X_{Q B}>0$ に対して、 ${ }_{S} \widetilde{Q}_{Y}\left(X_{Q B}\right) \leq s \bar{Q}_{Y}$

Q.E.D.

系 2. 問題 ODPR における免震層の最適降伏剪断力の上界

問題 ODPR において免震層の最適降伏塑断力 ${ }_{S} \check{Q}_{Y}\left(T_{f}\right)$ には 上界が存在し、 $\forall T_{f} \in B_{T f}$ に対して以下の不等式が成り立つ。

$$
\begin{aligned}
& { }_{s} \breve{Q}_{Y}\left(T_{f}\right) \leq{ }_{S} \bar{Q}_{Y}^{T} \\
& \text { ここに、 }{ }_{S} \bar{Q}_{Y}^{T}=\frac{(\kappa-1) V_{E}}{\kappa} \sqrt{\frac{M k_{0}}{2 \kappa-1}}
\end{aligned}
$$

${ }_{S} Q_{Y}=\frac{(\kappa-1) V_{E}}{\kappa} \sqrt{\frac{M k_{0}}{2 \kappa-1}}$ は図 1 の(4)点を表わしている。

ODPR の解は図 1 に破線で示すように(4)点を通る放物線上に 存在する。(4)点は、 $T_{f}$ が最小值 $2 \pi \sqrt{\frac{M}{k_{0}}}$ をとる時の解を示してお り、この時最適降伏剪断力が最大值をとることが分かる。

【系 2.の証明】(73) 式より明らかなように、 ${ }_{S} \breve{Q}_{Y}\left(T_{f}\right)$ は、 $T_{f}$ に関して単調減少関数であるから、 $T_{f}$ がその変域で最小值 $T_{f}=$ $2 \pi \sqrt{\frac{M}{k_{0}}}$ を取るとき最大値 $\frac{(\kappa-1) V_{E}}{\kappa} \sqrt{\frac{M k_{0}}{(2 \kappa-1)}}$ をとる。

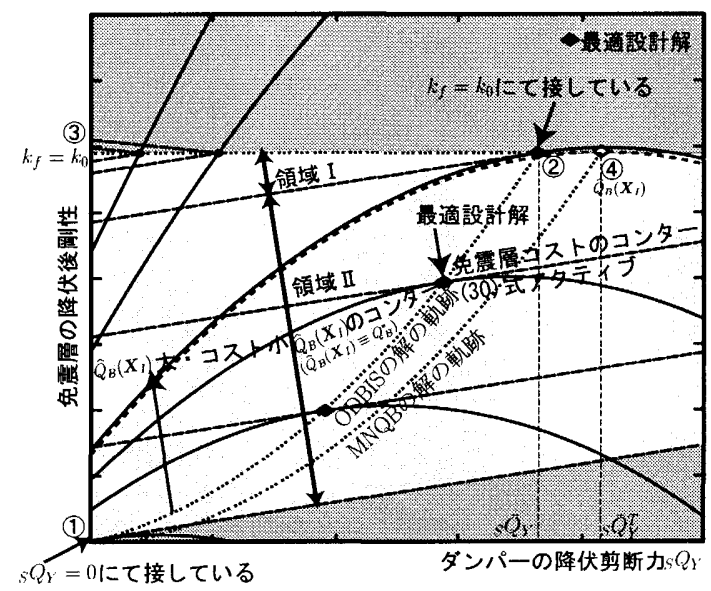

図 1 最適設計問題 ODBIS の解構造

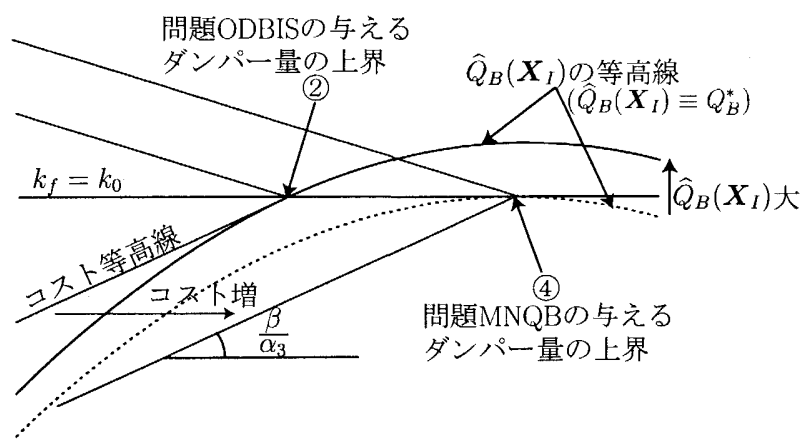

図 2 最適解近傍の拡大図 


\section{2 つの最適設計問題の比較}

本論文では、実務における設計手法の数理モデルとしての最適 設計問題と、免震建物のコスト最小化問題としての最適設計問題 をそれぞれ定式化した。

これら 2 つの最適設計問題の解の間には、不等式関係が成立す る。以下に示すような不等式関係を提示することで、著者らの提案 する最適設計手法と実務における設計手法の関係が明らかとなる。

\section{1 最適降伏剪断力の上界に関する不等式}

最適設計問題 ODBIS と、問題 ODPR の与える最適降伏剪断 力の上界の間には次に示す不等式関係が成立する。

系 3. 問題 ODBIS と問題 ODPR の最適降伏剪断力の上界の 間に成立する不等式

問題 ODBIS と問題 ODPR の最適降伏剪断力の上界の間に次 の不等式が成立する。

$$
{ }_{s} \bar{Q}_{Y} \leq{ }_{S} \bar{Q}_{Y}^{T}
$$

図 1 に示した ODBIS と ODPR の解の上界近傍の拡大図を 図 2 に示す。

両者の解は、何れも直線 $k_{f}=k_{0}$ 上にあるが、ODBIS の解は $\beta / \alpha_{3}>0$ なる傾きを有するコス卜等高線と免震層の最大応答剪断 力 $Q_{B}$ の等高線の接点となっているのに対し、ODPR の解は、傾 きが 0 である直線 $k_{f}=k_{0}$ と免震層の最大応答剪断力 $Q_{B}$ の等高 線の接点即ち放物線の頂点となっている。

このように、二つの最適設計解の上界は、免震層の最大応答剪 断力の等高線が接するべき直線の傾きによって特徴づけられ、図 2 より明らかなように、両者の間には式 (82) に示す不等式関係が成 立している。

以下、このことを数学的に証明する。

【系 3.の証明】

(82) 式の両辺を自乗して右辺から左辺を減じると、

$$
\begin{aligned}
& \left({ }_{S} \bar{Q}_{Y}^{T}\right)^{2}-\left({ }_{s} \bar{Q}_{Y}\right)^{2} \\
& =\frac{(\kappa-1) M V_{E}^{2} \beta}{\kappa(2 \kappa-1)^{2} \alpha_{3}} \sqrt{\left(\frac{M V_{E}^{2} \beta}{2 \alpha_{3}}\right)^{2}+(2 \kappa-1) M V_{E}^{2} \beta} \\
& \quad-\frac{\kappa^{2}+(\kappa-1)^{2}}{\kappa^{2}(2 \kappa-1)^{2}}\left(\frac{M V_{E}^{2} \beta}{2 \alpha_{3}}\right)^{2}
\end{aligned}
$$

ここで、(34) 式に示す不等式を用いて下式を得る。

$$
\left({ }_{S} \bar{Q}_{Y}^{T}\right)^{2}-\left({ }_{S} \bar{Q}_{Y}\right)^{2}>\frac{1}{\kappa^{2}(2 \kappa-1)}\left(\frac{M V_{E}^{2} \beta}{2 \alpha_{3}}\right)^{2}>0
$$

Q.E.D.

\section{2 免震建物の総コストに関する不等式}

免震建物を設計する場合、様々な尺度を持って合理性を追求し ながら解を求めることになるが、何を尺度にするかに関わらず総 コストを無視して設計解を決定することは出来ない。

従って、著者らが提案するコスト最小設計問題の解は、他のい かなる設計手法により得られる解よりも小さな総コストを与える、 即ち、総コストの下界を提示するものであるということは、重要 な点である。

ここでは、このことを示す一例として、 $C^{O D}\left(Q_{B}^{o p t}\right)((64)$ 式 $)$ と、 許容な指定一次固有周期 $T_{f}^{*}$ に対する問題 ODPR の解が与える総 コスト $C^{P R}\left(T_{f}^{*}\right)((77)$ 式)の比較を提示する。
系 4. 問題 ODBIS と問題 ODPR の最適解が与える建物総コ ストの間に成立する不等式

問題 ODBIS と問題 ODPR の与える免震建物の総コストの間 に次の不等式が成立する。

$$
\forall T_{f}^{*} \in \boldsymbol{B}_{T f} \text { に対して } C^{O D}\left(Q_{B}^{o p t}\right) \leq C^{P R}\left(T_{f}^{*}\right)
$$

系 4. が成立することは、 $C^{O D}\left(Q_{B}^{o p t}\right)$ が許容な設計解の与える コストの下界 (最適解) であることから自明であるので数学的証明 は割愛する。

\section{6 設計例による比較}

本節では、免震建物設計例から現実的な数值を取り入れること で、著者らが提案する設計手法と、実務における設計手法を定量 的に比較する。

ここで設計対象とする超高層免震建物の設計諸元は表 1 に示す 通りである7)。

表 1 設計諸元

\begin{tabular}{|c|c|c|}
\hline 定数 & 記号 & 值 \\
\hline 上部構造物の質量 & $M$ & $204.0 \mathrm{kN} \mathrm{sec} / \mathrm{cm}$ \\
\hline 地震入力エネルギーの速度換算値 & $V_{E}$ & $150 \mathrm{~cm} / \mathrm{sec}$ \\
\hline 積層ゴム支承の限界ばね定数 & $k_{0}$ & $295.1 \mathrm{kN} / \mathrm{cm}$ \\
\hline
\end{tabular}

この建物は、実際既に設計が完了しており、2 次設計時 $\left(V_{E}=\right.$ $150 \mathrm{~cm} / \mathrm{sec}$ ) の免震層の最大応答剪断力 $Q_{B}$ が $14500 \mathrm{kN}$ (ベース シヤー係数換算で $\left.C_{B}=0.073\right)$ となるように設計されている。

また、上・下部構造物の直接工事費も既に分かっているので、こ の時の直接工事費をコストの基準値とし、これ以降、コストにつ いては全てこの基準值を用いて基準化したコスト指標で表現する。 この時、免震層のコスト係数は表 2 のようになる。

表 2 コスト係数

\begin{tabular}{|c|c|c|}
\hline \multicolumn{2}{|c|}{ コスト係数 } & 值 \\
\hline 支承に関する係数 & $\alpha_{1}$ & $3.6 \times 10^{-4} \mathrm{~cm} / \mathrm{kN}$ \\
\cline { 2 - 3 } & $\alpha_{2}$ & $6.0 \times 10^{-4} \mathrm{~cm} / \mathrm{kN}$ \\
\hline ダンパーに関する係数 & $\beta$ & $1.74 \times 10^{-6} 1 / \mathrm{kN}$ \\
\hline
\end{tabular}

本例題の建物を 1 階部分で固定して求めた固有周期は 1.7 秒で ある。一般に免震周期が上部構造物の固有周期の $2 \sim 3$ 倍以上であ れば、上部構造物を剛体として扱っても問題ないことが知られてい る1)が、本例題では免震周期 $4 \sim 6$ 秒以上がその条件である。後に 示すように、本例題の最適解は免震周期 6 秒以上の帯域にあるの で、上部構造物を剛体として取り扱う本論文の仮定が妥当な範囲 にある。

本論文では上・下部構造の最適設計を問題 ODUL で行う方法を 提案しているが、ここでは簡単のため ODUL で得るべき上部構造 物のコスト関数 ((63) 式) を以下のような近似式で代替する。

$$
\begin{gathered}
\widetilde{C}_{U L}\left(X_{Q B}\right)=C_{U L}\left(\boldsymbol{X}_{U L}\left(X_{Q B}\right)\right)= \\
\quad 1.8 \times 10^{-6}\left(X_{Q B}-14500\right)+1.0
\end{gathered}
$$

上式は、上・下部構造物をべースシヤー係数換算で $C_{B}=0.35$ の地 震荷重即ち $X_{Q B}=70000 k N$ で設計するとコスト係数が 1.1 とな るという仮定のもとに求めた上・下部構造のコス卜関数 $\widetilde{C}_{U L}\left(X_{Q B}\right)$ の一次近似式である。

免震層の応答に関する制約条件は表 3 に示す通りである。 
表 3 制約条件

\begin{tabular}{|c|c|}
\hline 制約条件 & 制約条件式 \\
\hline 免震層応答変位に関する条件 & $\delta_{\max } \leq 50 \mathrm{~cm}$ \\
\hline 免震層尊断力に関する条件 & $Q_{B} \leq 14500 \mathrm{kN}$ \\
\hline
\end{tabular}

著者らの提案する設計手法では、上記の与条件のもとで免震層 の最適設計解を直接的に求めることが出来るが、実務の設計におい ては、構造設計者が先ず免震周期を決定しなければならない。こ の設計例の場合は、超高層免震建物であるため、免震装置に対す る引き抜き力を発生させないための条件式 $X_{Q B} \leq 14500 k N$ を 満たす免震周期を、過去の類似設計例を参照しながら仮に決定し、 試行錯䛊により適切と判断される周期が設定された。結果として、 免震周期をおよそ 6.4 秒と設定し、 $k_{f}=195.4 \mathrm{kN} / \mathrm{cm}$ とした。

以下に、2つの最適設計手法に基づく最適設計解とそれらの比 較を示す。図 3 に、2 つの設計手法に基づく解を図示する。

表 4 最適設計解

\begin{tabular}{|c|c|c|c|}
\hline & (1) ODBIS の解 & (2) MNQB の解 & (2)/(1) \\
\hline$k_{f}$ & $191.0 \mathrm{kN} / \mathrm{cm}$ & $195.4 \mathrm{kN} / \mathrm{cm}$ & 1.023 \\
\hline${ }_{S} Q_{Y}$ & $5658.7 \mathrm{kN}$ & $6766.0 \mathrm{kN}$ & 1.196 \\
\hline$C_{I}$ & 0.141 & 0.142 & 1.006 \\
\hline
\end{tabular}

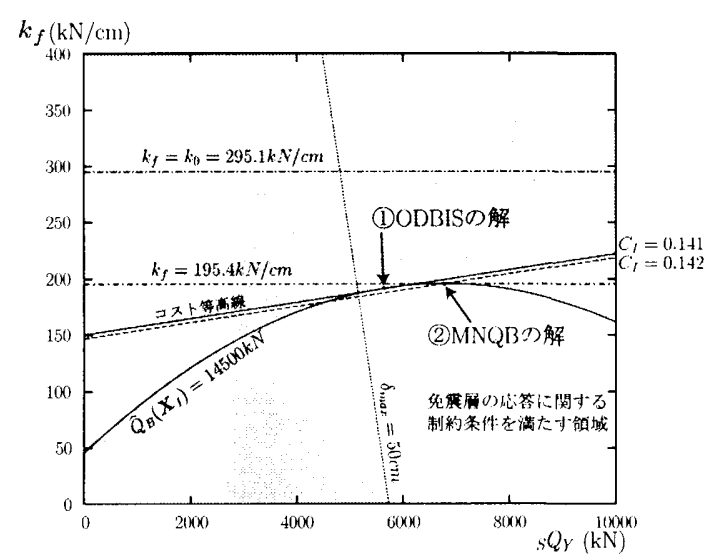

図 3 超高層免震建物の最適設計例

この設計例の場合、免震装置に引き抜き力を生じさせないため の制約条件が解を決定しており、何れの解も免震層の最大応答剪 断力 $X_{Q B}$ が $14500 \mathrm{kN}$ となる設計となっている。免震層の最大応 答剪断力が同じであるから、上・下部構造のコストは両者とも同じ で、建物全体のコストの差は、免震層のコストの差のみである。

本設計例では、両者の建物全体コストの差は $0.1 \%$ 未満と非常に 僅かである。免震層の設計変数については、 $k_{f},{ }_{S} Q_{Y}$ 共に、著者 らが提案する設計手法の方が小さな值を与える傾向があるが、值 の差は僅かであると言える。

この結果は、著者らが提案する設計手法が、これまで実務者が 活用してきた設計手法を否定するものではないことを示唆してい る。ダンパーのコスト係数 $\beta$ を 0 とおくと、著者らの提案する設 計手法の与える解と春務で用いられている設計手法の与える解は 一致する。

即ち、実務における設計手法は、ダンパーのコストを無視した コスト最小設計手法であると解釈できる。

\section{7 結論}

本論文の結論は以下のようにまとめられる。

1. 近年免震建物が高層化する傾向が見られるが、このような免 震建物においては、地震時において免震装置に引き抜き力を 生じさせないために従来の免震構造より長周期化を図る設計 が行われる。この場合は、免震建物の最大応答転倒モーメント に関する制約が免震周期を含む設計解を決定する問題となつ ていることを示した。免震建物の高層化のように、今後免震 構造の適用範囲が拡大したり、免震建物に要求される性能が より高度化することが予測されるが、著者らの提案する設計 手法では、制約条件式にそれらの条件を記述できる限り、複 雑化・高度化した問題でも直接的に解を求めることができる。

2. 著者らの提案する最適設計解の与えるコストは、その問題の 定義から明らかなように、免震建物の許容な設計解の与える コストの下界を与える。このように設計対象となる免震建物 に対して、要求される制約条件を満たす許容な解の下界を明 らかにすることは、設計者に対して設計上の判断のよりどこ ろとなる有用な情報を提供する。

3. 免震建物の最適設計手法により得られる免震層の最適解に関 する上界を提示した。包絡解析法に基づいて誘導されたこの 上界は、免震建物の動的解析の手法を等価線形化手法や時刻 歴応答解析法とした最適設計問題を解く際の初期解として用 いることが出来る。

4. 実務において活用されている設計手法を数理的にモデル化し、 著者らの提案する最適設計手法との比較を行った。設計例を 通して、前者の問題において免震周期の設定が適切であれば、 両者の解の差は僅かであることを示した。また、異なる二つ の問題において免震層最大応答剪断力が一致する場合、ダン パーのコスト係数を無視したコスト最小設計問題の解と、本 論文で提示した実務設計手法の数理モデルとしての最適設計 問題の解は一致することを示し、両設計手法の関係を明らか にした。

\section{荟考文献}

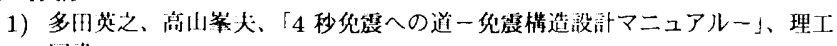
図暻, 1997.8

2) 日本建策学会, 货震棈造設計指針第 3 版

3) Bhatti M. A. and Pister K. S.:A dual criteria approach for optimal design of earthquake-resistant stractural systems., Earthquake Engineering and Structural Dynamics,9,pp.557-572.1981

4) Inaudi, J. A. and Kelly, J. M. ,:Optimum damping in liear isolation systems. ,Earthquake Engineering and Structural Dynamics, 123:9,pp. 897-971.1993

5) Sinha S. C. and Li G. N.:Optimum designing of base-isolated structures with dynamic absorber. Journal of Engineering Mechanhics, 120:2,pp.221-231,1994

6) Jeung-Geun Park and Hisanori Otsuka:Optimal Yield Bilinear Seismic Isolation Devices.

7）五十子幸樹、上谷宏二:一自由度近似を用いた免震構造物の最適設計，日本建 築学会構造系論文集 第 586 号,pp.87 94,2004 年 12 月

8）秋山宏:エネルギーの釣合に基づく建築物の耐震設計，技報堂出版,1999.11

9) H.W. Kuhn and A.W. Tucker : Nonlinear programming, in: J.Neyman (ed.), Proceedings of the Second Berkeley Symposium on Mathernatical Statistics and Probability (University of California Press, Berkeley, CA)pp.481-492,1951

10) G.L. Nemhauser, A.H.G. Rinnooy Kan and M.J. Todd (eds.): Optimization: Handbooks in Operations Research and Management Science, Vol.1 ,Elsevier, 1989.[邦訳 (伊理ほか監訳), 最適化ハンドブッ ク, 朝倉書店,1995]

(2004年10月 8 日原稿受理，2005年 4 月 25 日採用決定) 